\title{
Muslim Youths and Societal Development: The Case of Nasarawa State
}

\author{
Mohammed Maga Sule \\ Usmanu Danfodiyo University, Sokoto, Nigeria \\ e-mail: mohammed.maga@yahoo.com
}

\begin{abstract}
A linkage between Muslim youths and societal development is obvious and enduring since the time of the first Prophet on earth,Adam (A.S.). This interaction is connected symbiotically and, furthermore, one depends on the other for its sustenance. Therefore, the role of Muslim youths in the development of Nasarawa State cannot be ignored.The wheels of the development of a country rest on the shoulders of the youths. Consequently, the youths in Nasarawa State are the engine of the growth and development because they provide the labor force for the production of goods and services to take effect in the development of the state. Thus, the role of Muslim youths in the development of Nasarawa State is crucial for the entire developmental processes and aspirations of the whole society. In addition, the productive youths are acknowledged as the cornerstone for societal rejuvenation.
\end{abstract}

Keywords:

Youth, Social Development, Nasawara State

\section{Introduction}

The term "youth" means the time of one's life between adolescent and adulthood, especially before a child becomes an adult (Turnbull 2010:1730). In terms of an individual's level of dependency, "youth" can be marked in various ways according to different cultural perspective referring to young people who still rely on their family emotionally and economically (Furlong 2012:2-3). In Nasarawa State, the population 
of youths is about $47 \%$. According to Nigeria National Youth Policy, any individual with the ages between 18-35 years are regarded as youth whereas the United Nation describes anyone within the age of 15-24 years are categorized as youth. Meanwhile, the Common Wealth of Nations recognizes those with the age between 16-29 years as youth. However, in Nigeria, the youths have the larger percentage of active population, in terms of their economic and political roles. It is important to underline that youths represent a fundamental group to make Nigeria to be a greater nation(Gandi 2015:1).

Young age is a period of great change and hope for the future. It can be the happiest and most productive time of a person's life, yet this stage of development can also be fraught with numerous psychological, sociological and spiritual crises. Because the young people of any society carry the future of their nations on their shoulders, their problems and troubles should be of an utmost concern for the people around them. Furthermore, the solutions to these difficulties must be practical and concrete.

In terms of Islamic teaching, young people who follow Allah's guidance would be the source of pride, inspiration, and strength for the global Muslim community. They would offer hopes for the future and sollutions for the problems of the world. Their reward lies not only in this world but in the external life to come (Uthaymeen 2011:33). A society can only be made by those who live in it; religion can also stand firmly only by the help of its adherents. Whenever they stand by it, Allah makes them victorious no matter whom their enemies are (Uthaymeen 2011:25). If a religion cannot stand except with the help of its adherents, we (the people of Islam and its flag bearers) are then obliged to set ourselves straight so that we may qualify to lead and guide others and subsequently deserve success from Allah (Uthaymeen 2011:25). It is therefore incumbent upon the youths to put into action all that we learned which emanates from faith, conviction, sincerity, and following the sunnah.

DINIKA, Volume 3, Number I, January - April 2018 


\section{The Concept of Youth in Qur'an}

Islam has provided a perfect code of life which addresses human concern at all stages of life regardless of status, gender and ethnicity. Allah the Creator has bestowed upon humanity complete guidance which if understood and followed, offers direction to even the most troubled minds and hearts. And anybody who sticks to that guidance will have a successful life in the world and in the hereafter. The Qur'an is the book of Allah that covers the entire life of human endeavor since cradle to grave including young age. The word youth appears fourteen times in the Qur'an using four different words. These are all contained in the following verses of the Quran. Allah says,

"And we have enjoined upon man, to his parents, good treatment. His mother carried him with hardship and gave birth to him with hardship, and his gestation and weaning is (period) thirty months. Until, when he reaches maturity and reaches (the age of) forty years, he says, ${ }^{1}$ 'And whoever of you have not the means wherewith to wed free believing women, they may wed believing girls from among those whom your right hand possession."'2

In this particular verse, the word "Fataya-tikum" means slave girls (young girls) which are allowed to be wedded by believers who have no means to marry or free the girl. Allah says in another place, "And women in the city said: 'the wife of the Aziz is seeking to seduce her (slave) young man." 3 This refers to Prophet Yusuf (A.S.) and what happened between him and the wife of a king when she intended to have sex with him and he ignored and refused her demand. In another place, the word "Fatayaan" was used to means two young men (i.e. those in prison with Prophet Yusuf A.S) as contained in the following verse: Allah says, "And there entered

\footnotetext{
1 Qur'an, Surat Al- Ahqaf, 46:15.

2 Qur'an, Surat An-Nisaa, 4:25.

3 Qur'an, Suratul Yusuf, 12:30.
} 
with him two young men in the prison..." Allah uses the word youth as "Fityatu" which means young men in this verse, Mention) when the youths retreated to the cave and said, "Our Lord grants us from Yourself mercy and prepare for us from our affair right guidance"

Here Allah tells us about those young men who fled from their people for the sake of their religion, fearing persecution. So they fled taking refuge in the cave of a mountain, where they hide from their people. In another place the word youth is used as "Fityatumn" (young men) as follows: It is We who relate to you, (O Muhammad), their story with truth. Truly they were youths who believed in their lord (Allah) and We increased them in guidance. ${ }^{6}$ This means young boys from the boys of paradise will go around serving the people of paradise, in one stage of life forever which they will be never changing from (i.e. everlasting youth). These are the places in the Qur'an where the word youth appeared with different words but the same meaning.

\section{The Concept of Youth in Hadith}

In hadith, the Prophet (S.A.W.) addressed Muslim youths in different aspects. Reference is made to some hadiths that talk about young people and also underline the merit of youthfulness, the enviable position young people occupied in the heart of the messenger of Allah (S.A.W) and the care he had for their welfare, their religious discipline and self-control, the highly commendable role they played during the time of Prophet (S.A.W) in demonstrating a high sense of responsibility and generosity, their gallant fight in the cause of Allah and the sacrifice of their most valuable possession in order for the religion of Allah to prevail. Also the confidence that our rightly-guided predecessors had in them by assisting them the most arduous tasks and the everlasting reward that awaits them

\footnotetext{
4 Qur'an, Suratul Yusuf, 12:36.

5 Qur'an, Surat Al-Kahf, 18:10.

6 Qur'an, Surat Al-Kahf, 18:13.
}

DINIKA, Volume 3, Number I, January - April 2018 
on the Day of Judgment. Abu Huraira (RA) reported that the Apostle of Allah (S.A.W) had said,

"Seven are (the persons) whom Allah would give protection with His Shade on the day when there would be no shade but that of Him: A just ruler, A youth who grew up with the worship of Allah, A person whose heart is attached to the Mosques; Two persons who love and meet each other and depart from each other for the sake of Allah; A man whom a beautiful woman of high rank seduces (for illicit relation), but he (rejects this offer by saying): "I fear Allah" A person who gives charity and conceals it (to such an extent) that the right hand does not know what the left has given: And a person who remembered Allah in privacy and his eyes shed tears."(Al-Munthiri, n.d.:537).

Look at the importance that Allah has given to the period of youth. The acts of all these seven groups of people are "easy to say" but "difficult to do". The more the difficult the test, the greater the reward would be in the sight of Allah.

\section{The Concept of Youth from the Views of Muslim Scholars}

Muslim Scholars have expressed their views on youth and youthful ages, according to Shaykh Muhammad Salih al-Uthaymeen, he states that youth is a time of great change and hope for the future. It can be the happiest and most productive time of a person's life, yet this stage of development can also be fraught with numerous psychological, sociological and spiritual crises. Because the young people of any society carry the future of their nations on their shoulders, their problems and troubles should be of utmost concern for everyone around them and solutions to these difficulties must be practical and concrete (Uthaymeen 2011:26). He further categorized young people into three classes and concluded that the first class is the pride of this ummah and the symbols of its life, its prosperity, and its religion. They are those whom we hope Allah will use 
to repair the Muslims and shall attain the bliss of this world and next as Allah will.

On the other hand, the scholar says, corrupt young people are young people who are religiously deviated, behaviorally reckless, self-deluded and engulfed by their own vices. They do not accept truth from others, do not refrain from the falsehood that is inherent in their minds and are selfish in their conduct. They are obdurate, do not give truth a chance, and do not care that they neglect obligations that are due to Allah or those that are due to human beings.

They are a calamity to themselves and a catastrophe to their society. They bring this ummah down to the lowest of the low, obstructing its way to glory and honor. They are like a deadly disease that is not easily curable except by the will of Allah Alone, who is All-powerful (Uthaymeen 2011:27).

Finally, in the last category, the scholar explained that, the confused young people are the ones who are uncertain, irresolute, and at a crossroad. They know the truth and are sure of it. They live in a religions conservative society but have the misfortune of being exposed to evils like skepticism about the truthfulness of the Muslim creed, corruption in conduct and behaviors, decadence in action, attacks on the established customs and traditions, and other various absurd trends. They can free themselves from this confusion, however, by concentrating on Islamic education and learning it from its original source, the Qur'an and the sunnah, with the help of sincere scholars (Uthaymeen 2011:34).

\section{The Concept of Societal Development in Glorious Qur'an}

The Islamic way of life is based on a unique concept of man's place in the universe (Maududi 2017). The Islamic society is unique in its structure, composition and its characteristics. These characteristic are depicted from the Qur'an and Hadith. The following is characteristics of

DINIKA, Volume 3, Number I, January - April 2018 
an Islamic society as contained in Qur'an. These three characteristics are summarized in the Qur'an Allah the exalted says, "You are the best of peoples, evolved for mankind, enjoining what is right, forbidden what is wrong and believe in Allah."7

The Islamic shariah divides enjoining what is right (al-Ma'ruf) into three categories: The mandatory (Fard and Wajib), the recommendatory (Mandub) and permissible (Mubab). The observance of the mandatory is obligatory on Muslim society and the shariah has given clear and binding directions about this. The recommendatory (al-Ma'ruf) are those which the shariah expects a Muslim society to observe and practice. Some of them have been very clearly demanded of us while others have been recommended by implication and inference from the sayings of the Prophet (SAW). Besides, special arrangements have been made for the growth and encouragement of some of them in the scheme of life advocated by the shariah. Others again have simply been recommended by the shariah, leaving it to the society or to its more virtuous elements to promote them.

This leaves us with the permissible (al-Ma'ruf). Strictly speaking, according to the shariah, everything which has not been expressly prohibited is permissible. Consequently, the sphere of the permissible is very wide, so much so that except for the things specifically prohibited by the shariah, everything is permissible for a Muslim. And in this vast sphere, we have been given freedom to legislate according to our own direction to suit the requirement of our time and its dictates. On the other hand, forbidden is what is bad (Munkar) which has been grouped into two categories. Things which have been prohibited absolutely (haram), and things which are simply undesirable (makruh). The Islamic society is based on moderation and it is an ummah of moderation. This concept of community of moderation is explained in the Qur'an very nicely. Allah says, "Thus have we made of

$7 \quad$ Qur'an, Surat Aal-Imran 3:110.

DINIKA, Volume 3, Number I, January - April 2018 
you an ummah justly balanced, that you might be witness over the nations and the Apostle a witness over yourselves."

Also, the Islamic society is one single ummah. This concept of being one Muslim community is clearly explained to the following verse Allah which says, "Verily, this brotherhood of yours is a single brotherhood, and I am your lord and cherisher; therefore worship me (and no other.)" Nevertheless; Islamic society is based on consultation. Allah designated a whole chapter in the Qur'an under the title of consultation (Ash-shura). Allah says, "And those who have responded to their lord and established prayer and whose affairs is (determined by) consultation among themselves, and from what We have provided them, they spend." ${ }^{10}$

The Islamic society is also built on the concept of brotherhood. Muslims are ordained to have the feelings and application of concept of brotherhood. Allah says in the Qur'an, "The believers are but single brotherhood... ${ }^{11}$ Allah says in the Qur'an; O you who believe! Fear Allah as He should be feared, and died not except in the state of Islam." ${ }^{12}$ One important characteristic of the Islamic society is the concept of Jihad. Jihad is to be for the sake of Allah, i.e. to apply rules and regulations of Allah, and for the pleasure of Allah. Jihad is meant to defend the land of Islam and defend the Muslims themselves.

\section{The Concept of Societal Development in Hadith}

The Islamic society is unique in its structure, composition and its characteristics. These characteristics are stated in badith of Prophet (S.A.W). The following are some of characteristics of Islamic society as contained in the badith. One of the characteristic is brotherhood which was explained

8 Qur'an, Surat Al- Baqara 2:143.

9 Qur'an, Surat Al-Anbiyaa 21:92.

10 Qur'an, Surat Ash-Shura 42:38.

11 Qur'an, Surat Al-Hujuraat 49:10.

12 Qur'an, Surat Aal-Imran 3:102.

DINIKA, Volume 3, Number I, January - April 2018 
in the Hadith of Prophet (S.A.W) which has been narrated by Al-Nu'man bin Basheer that Prophet Muhammad (S.A.W) said, "The similitude of the believers in their kindness mercy, affection and compassion toward one another is like a body, when one organ ills, the whole body is drafted to take care of the problem." (Al-Munthiri, n.d. hadis no. 1774).

This particular Hadith clearly shows that Muslims are single society irrespective of their tribe, colour, race and culture, therefore they should leave like brothers and sisters no matter the condition they found themselves. Advice is another characteristic of the Muslim ummah. Prophet Muhammad (S.A.W) said as narrated by Abu Ruqayah Tamim Bin Awss Al Dari that the Prophet (S.A.W) said;

The religion is Advice. We asked; for whom? He said: for Allah, for His book, for His messengers, for the Imams of the Muslims and for the rest of the Muslim ummah. ${ }^{13}$ This is another important instrument in living with one another; whenever Muslim ummah imbibes the culture of advising each other there will be harmony, tranquility and mutual understanding in the Muslims community. The prophet (S.A.W) said, "There is one hundred and ten (110) obedience to any creature while disobeying the creator." (AlMunthiri, n.d. hadis no.1095).

Therefore, whenever a leader commended what is good its compulsory for the general society to obey him and disobey him when he disobeyed the command of Allah and that of His Messenger. The Prophet Muhammad (S.A.W) said, "If any community leaves Jihad behind them, Allah is to prevail punishment on them." ${ }^{53}$ However, if Muslims today do adhere to such characteristics and apply them in their lives, many of their daily problems will be solved.

13 Imam An-Nawawih, 40 Collection, Hadith No: 21. 


\section{The Concept of Societal Development From the Views of Muslim Scholars}

Muslim scholars have a vital role as regards to the establishment of an ideal Muslim society. According to Abul Ala Maududi, a group of people or society which consists of true Muslims can never break away from the law of their lord. Its political order, its social organization, its culture, its economic policy, its legal system and its international strategy must all be in tune with the code of guidance revealed by Allah. Any unwilling contraventions must be corrected as soon as they are realized. It is disbelievers who fell free from Allah's guidance and behave as if they were their own master. Anyone who behaves like this even though he may bear a name similar to that of Muslim, is treading the path of the disbelievers (Maududi 2017).

Muhammad Ali Al-Hasim states in his writing that one of the most important distinguishing characteristics of the true Muslim society is that they measure every known custom of their society against the standards of Islam. Thus, all of their social values are derived from their understanding of the basic principles of their religion (Al-Hashimi 2005:335). Finally, he said other habits which Muslims should discard include having pictures and status in the house and keeping a dog at home (unless it is a guard dog). Islam strongly opposes these practices, and several hadiths expressly forbid the believers to adopt them.

\section{The Role of Muslim Youths to the Development of Society in Nasarawa State}

In this section, effort is made to exhaustively bring out and discuss the major contribution of Muslims youths in the promotion and development of society in Nasarawa State. These contributions indicated the level of commitment exhibited by Muslim youths in their effort to eradicate ignorance, illiteracy and social vices among the people of the state and to educate them on their rights and religions obligations.

DINIKA, Volume 3, Number I, January - April 2018 


\section{Youths Contribution to the Development of Islam}

Islamic religion emphasizes on admonishing and calling people to the true practice based on the understanding and interpretation of Salaaf Salih. This awakens Muslims (male and females) to rise for the important task to seek for knowledge and disseminate same to others where Islam is less practiced. In recognition of the importance of knowledge in Islam, Muslim youths had contributed immensely to the development of Islam in Nasarawa State especially in many areas of religious endeavor such as Da'wah activities, conversion campaigns to rural areas where Islam has not reached, Ramadan Tafsir, Hajj training program, organization of study groups and counseling services, Qur'anic studies/competitions which would be discussed below.

\section{Contribution in Da'wah Activities}

Muslim youths in the area studied have designed a series of Da'wah and religious activities in different places in order to offer their contributions in order to spread Islam in the area. National Council of Muslim Youths Organization (NCOMYO) Nasarawa State chapter is the mother body of all organizations established by the youths to carry Islamic activities and outreach programs to the villages where there are still pagans. Under the auspice of NCOMYO, youths carry out programs when some problems affecting the Muslims arise. The youths organize forum for dialogue and roundtable discussions for the disputing parties in presence of Islamic scholars and elders. This normally takes place on weekend i.e. Saturdays and Sundays for proper attendance by the public to achieve the desired intention. ${ }^{14}$

14 Interview with Ustaz Bashir Yahaya, Ameer NACOMYO, 37 years, December 15, 2016. 


\section{Conversion Campaigns}

One of the major activities of Da'wah program of Muslim youth Organizations is the conversion of non-Muslims to Islam. Although all the original inhabitants of Nasarawa State are Muslims, the Muslim Youth Organization started to spread Islam to the areas where the religion has few adherents. This is why the Nasarawa State chapter engaged in the conversion of non-Muslims outside Nasarawa State. This takes them as far as Tiv Land in Benue State and Berom and Goemai ethnic groups in Plateau State. This was jointly done with Benue and Plateau State chapters of the Youth Organizations. As a result of the outreach activities, more than 3,000 unbelievers accepted Islam in the visited areas. In order to give solid Islamic foundation, Islamiyah schools were established in the areas to educate the new converts the basics of Islam and recitation of the Qur'an ("Special Report on Federation of Muslim Women Association of Nigeria (FOMWAN) 20th Anniversary, 1990-2010," n.d.:51). However, the converts are faced with problems of abandonment by their families for accepting Islam. Many young girls who were neglected by their parents for accepting Islam were brought up, educated and married off to Muslims. ${ }^{15}$

\section{Contribution to Qur'anic Study/Memorization}

In this aspect, Muslim youths played a vital role in this regards by recitation of the Qur'an on monthly basis which has recorded a tremendous improvement in terms of the number of people reciting Qur'an fluently and faultless in the area studied. Under the auspices of FOMWAN in Nasarawa State, monthly Qur'anic recitations were organized, to encourage women to improve their knowledge of the religion. Similarly, in conjunction with FOMWAN, Muslim youths in the State were able to establish Islamiyah Schools at different sections of the State to enhance Islamic education

15 Interview with Rabi'a Suleinman Umar, Assistant Coordinator FOMWAN, Nasarawa State Chapter, December 24, 2016.

DINIKA, Volume 3, Number I, January - April 2018 
and provide sustainable learning process ("Special Report on Federation of Muslim Women Association of Nigeria (FOMWAN) 20th Anniversary, 1990-2010," n.d.53:). Also, Muslim Students Association on Nigeria (MSSN) Nasarawa State Area Unit organiz this program during Islamic Vacation Course (I.V.C.) annually, where participants are drawn from all secondary schools to participate in the Qur'anic memorization event and the winners are awarded with gifts as motivation to other youngsters. ${ }^{16}$

\section{Refresher Courses/Extra Moral Classes}

This is another contribution of Muslim youths in educational development of Nasarawa State. They assist in revising curriculum of senior high schools in order to prepare candidates that would sit for West African Examination Council (WAEC), National Examination Council (NECO), Joint Admission and Matriculation Board (JAMB), etc. The program is organized annually by the Muslim Youths Organizations in the State for sciences, social sciences and arts students in all the local government areas in the State, months before their final senior secondary school examinations (SSCE). During the program, teachers/facilitators are invited from secondary schools, polytechnic, college of education and university to teach the students voluntarily during weekends i.e. Saturdays and Sundays only. Some of the beneficiaries of these programs usually excel in all their papers which paved way for their successes in securing admission into tertiary institutions of learning. ${ }^{17}$

\section{Public Enlightenment/Seminar Program/Symposium}

The youth organizations organized different symposia and public lectures geared towards the development of Islamic and Western education

16 Interview with Ameer MSSN, Nasarawa State Area Unit, 45 years, January 09, 2017.

17 Interview with Ameer MSSN, Nasarawa State Area Unit, 45 years, January 30, 2017.

DINIKA, Volume 3, Number I, January - April 2018 
in the area studied because Muslims lag behind in the acquisition of Western education especially medical health practitioners. In this regards, general public were invited to the venue where current issues affecting the society were presented according to Islamic dimension. Also, prominent Islamic scholars were invited to present lectures on issues affecting the society especially the youths. Furthermore, Muslim Coppers Association (MCAN) Nasarawa State Branch has tremendously contributed in this aspect, especially in one of its programs called "Muslim Coppers Forum". During the program, Muslim Corps Members were invited from different areas of the State and lectures were presented to them on different Islamic topics. For instance, a lecture presented in February, 2016 on the "Islamic Perspective of Economic Melt Down in Nigeria" and "Life in the Grave" was also presented on $13^{\text {th }}$ March, 2016. ${ }^{18}$

\section{Contribution to Economic Development}

Islam is an all-encompassing religion, economic activities inclusive, which emphasizes self-reliance and independence for the betterment of one's life. Muslim youth embark on business ventures centered on youth and Women empowerment through skills acquisition programme and intellectual study, where monthly salary is paid teachers in different center that teach youths and women that art of trade and skill empowerment, which at the end of the exercise, a capital for starting entrepreneurship was disbursed to the trainees. Also, the Muslim youths in collaboration with other Muslim Ummah raise funds in order to finance the skills acquisition scheme and give capital to those that want to start Small and Medium Scale Enterprises. ${ }^{19}$

18 An oral Interview with Uthman Salisu, 29 years, Ameer Muslim Corp Members Association of Nigeria (MCAN), Nasarawa State Chapter, November 29, 2016.

19 Interview with Ustaz Bashir Yahaya, Ameer NACOMYO, 37 years, January 30, 2017.

DINIKA, Volume 3, Number I, January - April 2018 


\section{Contribution to Social Development}

In this aspect, Muslim youths in Nasarawa State has contributed immensely to the social development of the State in different aspects of life. These contributions were enumerated as follows: in collaboration with different agencies, a mutual understanding was established between the Muslim youth, Government and Non-Governmental Organizations (NGOs) in the Nasarawa State. This has produced synergy for social development of the area studied and attainment of the set objectives. For example, National Council of Muslim Youth Organization (NACOMYO) has different programs in collaborations with Non-Government organizations (NGOs) like Kungiyar Zaman Lafiya, Government agencies like, National Drugs Law Enforcement Agency (NDLEA), Federal Road Safety Corps (FRSC) and Independent Corrupt Practices Commission (ICPC) etc. These collaborations were made in order to give a positive result, share information, knowledge, ideas and help in sensitizing the people of Nasarawa State on different issues that would provide solutions for the betterment of their life and society in general. ${ }^{20}$

Environmental Sanitation: This is another area that the Muslim youths in Nasarawa State focus on for the social and religions development of the area. For example, Imam Malik Islamic Foundation has designed a weekly sanitation program to Jummu'at Masajid, cemeteries in the State which was later changed to monthly activities for the Islamic and social development in the area under study. Timetable were made according to the priorities, all the Jummu'at Masajid within the metropolis were covered on some date for sanitation activities. ${ }^{21}$

Medical outreach is also a societal development program by the Muslim youths. In this regard, medical team of Corps Members serving in

20 Interview with Ustaz Mustapha Usayn, Organizing Secretary NACOMYO, 37 years, January 31, 2017.

21 Interview with Isah Umar Adam, 35 years, Nassarawa Eggon Town, January 31, 2017.

DINIKA, Volume 3, Number I, January - April 2018 
the State involves in free medical treatment especially in some rural areas of the State, and collaborated with other local and international agencies like United Nations International Children Emergency Founds (UNICEF), Islamic Medical Association of Nigeria (IMAN) etc. in treating diseases like polio and malaria. In some cases, they engage in public enlightenment campaign on disease prevention and healthcare education. ${ }^{22}$

\section{Conclusion}

There is a sight of hope of living in an area, relatively free from religious, educational, economic, social and political problems in the future if the youths keep the tempo and momentum of Islamic activities. However, it needs unity of purpose among various Islamic sects (Sunni and Sufis) to promote moral values and positive spirited visions and dreams. It has become incumbent upon Muslim youths to realize the strength of unity, responsibilities and duties as Muslims and stand up for what is right being the vehicle that would take this religion to the next generation because if they failed to do so, Allah (S.W.T) would replace them with those that can discharge the duties diligently and dutifully. A fervent vision to the Prophet (S.A.W) model of youths suffice development, government and society to take cue in the discharge of their responsibilities to equip young generation with tools and skills to address problems ranging from environmental pollution, peer pressure, character building and civic responsibility. In sum, the effort of Muslim youths in Nasarawa State has yielded good results and impacted positively to the development of society at large.

22 An oral Interview with Uthman Salisu, 29 years, Ameer Muslim Corp Members Association of Nigeria (MCAN), Nasarawa State Chapter. January 31, 2017.

DINIKA, Volume 3, Number I, January - April 2018 


\section{References}

Al-Hashimi, M. 2005. The Ideal Muslim,. Saudi Arabia: International Islamic Publishing House.

Al-Munthiri, Abdul-Azim Zakiuddin. n.d. Sabih Muslim English Translation. Darus-Salam Publishers.

Furlong, Andy. 2012. Youth Studies: An Introduction. London: Routledge.

Gandi, I. 2015. "The Need for Youth to Be Patriotic to Become SelfReliant, News Analysis on Rima Radio Nasarawa."

Maududi, Abul Ala. 2017. "The Islamic Concept of Life." Accessed January 20. www.islam101.com/sociology/conceptLife.htm.

"Special Report on Federation of Muslim Women Association of Nigeria (FOMWAN) 20th Anniversary, 1990-2010.” n.d.

Turnbull, Joanna. 2010. Oxford Advanced Learners Dictionary. 8th Editio. Oxford: Oxford University Press.

Uthaymeen, Muhammad Salih Al-. 2011. Youths Problems. Riyadh, Saudi Arabia, International Islamic Publishing House. 
DINIKA, Volume 3, Number I, January - April 2018 